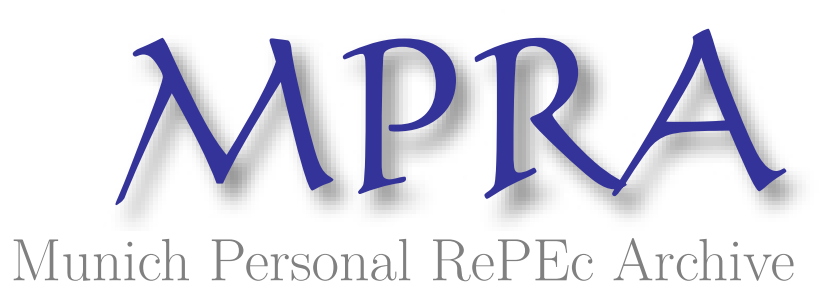

\title{
Currency crises in Russia and other transition economies
}

Popov, Vladimir

October 2001

Online at https://mpra.ub.uni-muenchen.de/28117/

MPRA Paper No. 28117, posted 19 Jan 2011 09:40 UTC 


\section{Draft, October 2001 \\ CURRENCY CRISES IN RUSSIA AND OTHER TRANSITION ECONOMIES 1}

\section{Vladimir Popov 2}

In recent years currency crises affected not only Southeast Asian countries, but transition economies as well. The Russian crisis of August 1998 was perhaps the most spectacular example, but it was preceded by currency crises in Bulgaria and Romania in 1996-97, in Ukraine and Belarus in 1997-98 and followed by the currency crisis in Kyrghyzstan and Georgia in late 1998, and in Kazakhstan in early 1999. Were these crises the result of financial contagion spreading in the global economy? Or were they of "the national making", but caused by reasons similar to that in Southeast Asia? The paper argues that neither of the above explanations is true and embraces a third explanation: currency crises in transition economies resulted mostly from domestic policy mistakes, but of different nature than those in Southeast Asia.

\section{The story: Russia's 1998 financial collapse}

Perhaps the most impressive of all currency crises that affected transition economies was the one that broke out in Russia in August 1998: in a matter of days the exchange rate that retained stability during the preceding 3 years lost over $60 \%$ of its value - more than in all most Latin American and Southeast Asian countries, except for Indonesia (fig. 1, 2); prices increased by nearly $50 \%$ in only 2 months after the crisis, as compared to less than $1 \%$ monthly inflation before the crisis (fig. 3, 4); and real output fell by about $6 \%$ in 1998 after registering a small increase of $0.6 \%$ in 1997 for the first time since 1989 (fig. 5).

Macroeconomic stabilisation of 1995-98. What is worse, the financial collapse in Russia marked the failure of the government program of macroeconomic stabilisation that was pursued for over 3 years with a fair degree of success. After experiencing high inflation of several hundred and more percent a year during the period immediately following the deregulation of prices on January 2, 1992, Russia finally opted for the program of the exchange rate based stabilisation. In mid 1995 the Central Bank of Russia (CBR) after accumulating foreign exchange reserves and managing to maintain the stable rate of the rouble for the first half of 1995, introduced a system of the crawling peg - an exchange rate corridor with initially pretty narrow boundaries (fig. 6).

\footnotetext{
${ }^{1}$ This paper draws heavily on my articles and papers listed in references and on the book The Asian Crisis Turns Global (by M. Montes and V. Popov, ISEAS, Singapore, 1999

http://www.iseas.edu.sg/pub.html). The updated Russian edition of the book was published in 1999 under the title "Asian Virus or Dutch Disease: Theory and Evidence of Currency Crises in Russia and Elsewhere" (Delo Publishers).

${ }^{2}$ Academy of National Economy (Moscow) and Institute of European and Russian Studies (EURUS), Carleton University (Ottawa).
} 

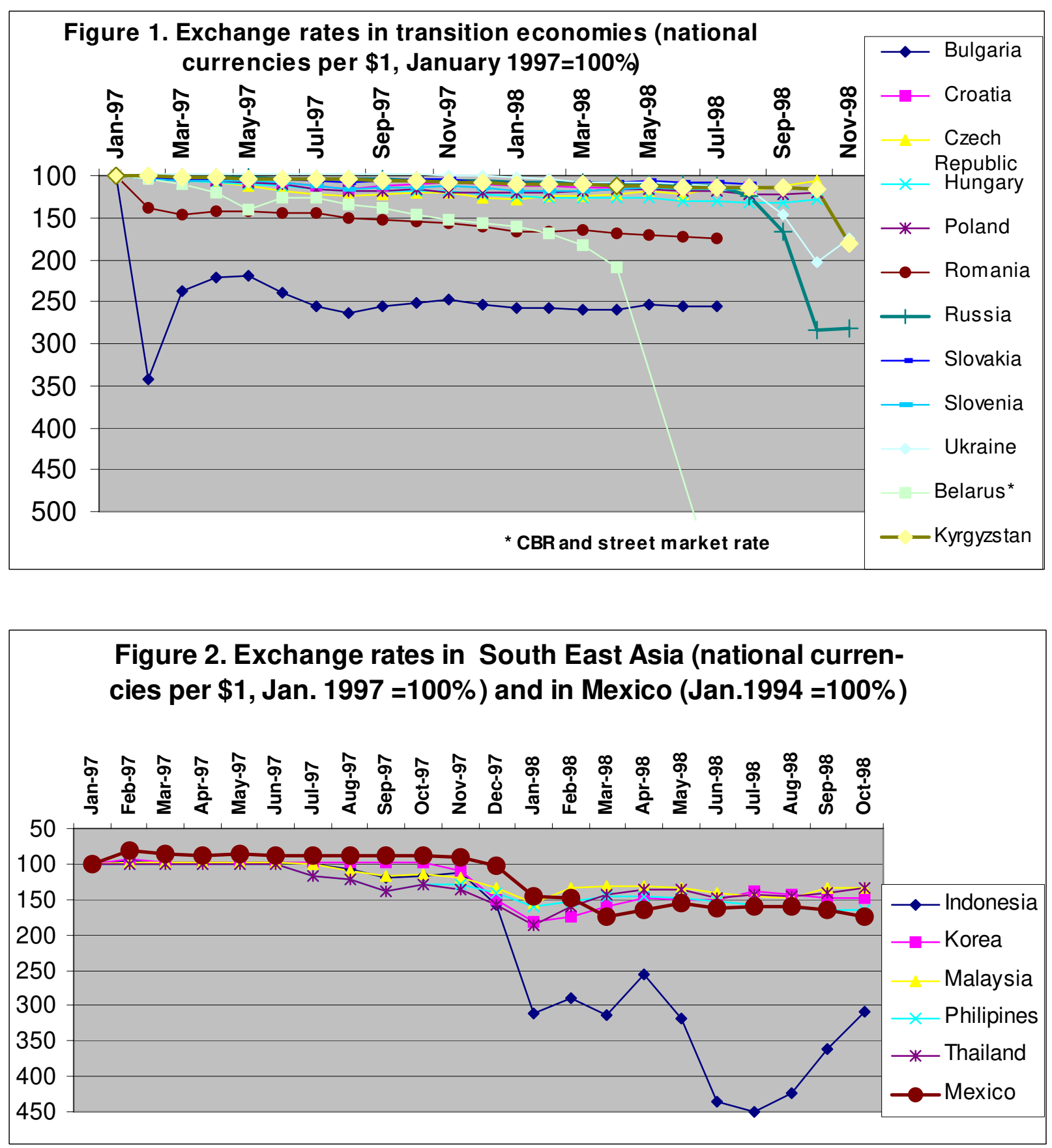

Source: International Financial Statistics and Central Bank of Russia. 

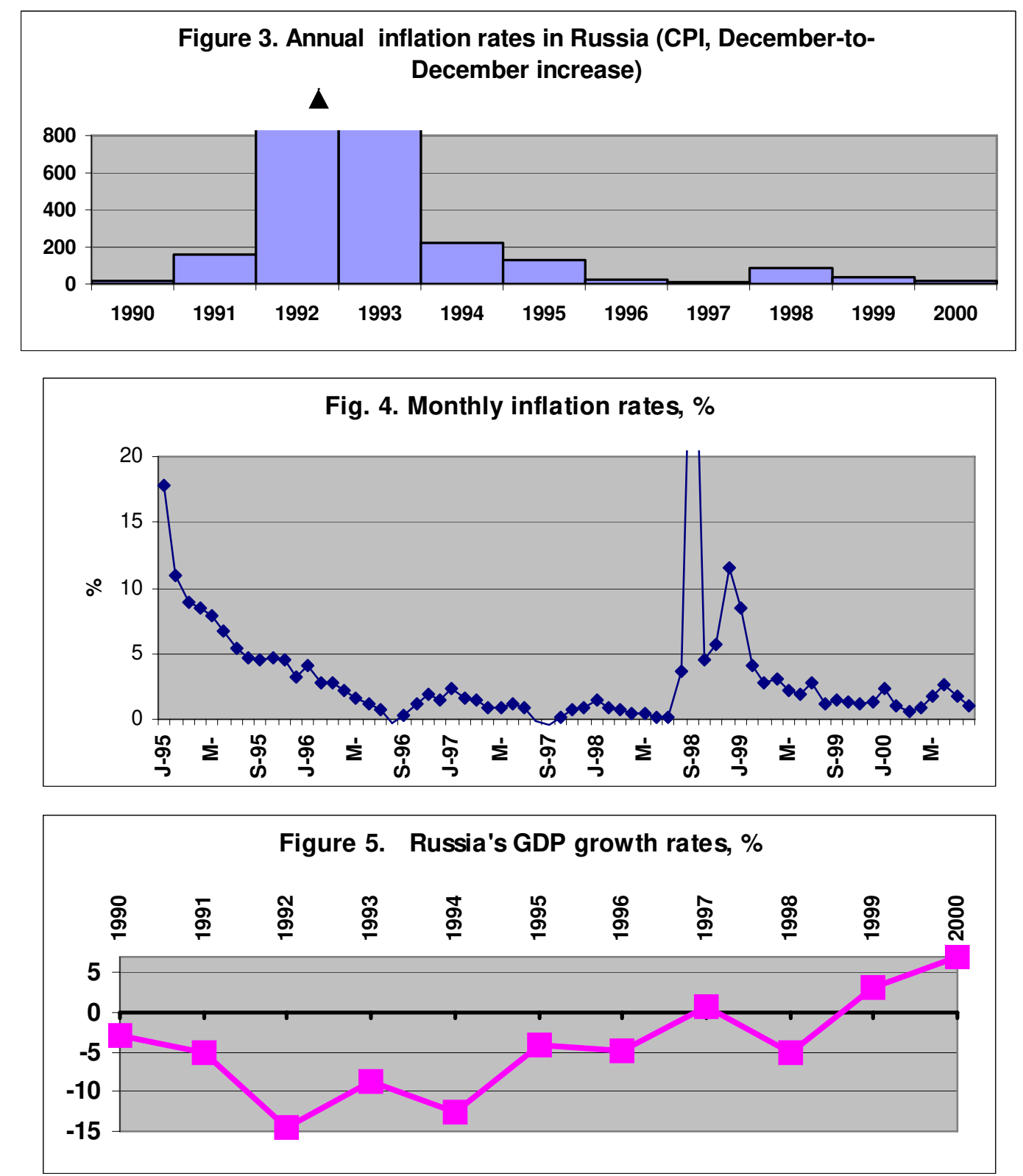

Source: Goskomstat.

The program was based on the government and the CBR decisiveness to bring down the rates of the growth of money supply and thus to curb inflation. The key to the program was to contain within reasonable limits of the government budget deficit and to find noninflationary ways of its financing. On both fronts the government stood up to its promises for three long years. It managed not to increase the budget deficit, even though this required drastic expenditure cuts since the budget revenues, despite all efforts to improve tax collection continued to fall (fig. 7). It also managed to finance the deficit mostly through borrowings - partly by means of selling short-term rouble denominated treasury bills (which were also purchased by foreign investors), partly by borrowing abroad in hard currency from international financial institutions, Western governments and banks and at the Eurobond market. Under such conditions the CBR got the opportunity to 
ensure the reduction of the rates of growth of money supply and a fall in inflation (fig. 3, 4).

Weak foundations of the macrostabilisation. Thus, macroeconomic stabilisation became a reality. Inflation right before the crisis was running at only 6\% a year (July 1998 to July 1997), the rates of the reduction of output in 1997 slowed down and the country was looking forward to economic growth. The macroeconomic stabilisation, however, was based on a weak foundation of the overvalued exchange rate of the rouble and on the policy of the CBR to keep the real exchange rate intact, i.e. to proceed with the devaluation of the nominal rate in line with the ongoing inflation.

As a result, the "Dutch disease" developed in Russia, since 1995, when the exchange rate of the rouble approached some $70 \%$ of the purchasing power parity (PPP) and stayed at this level until the crisis (fig. 6). The previously high export growth rates slowed down substantially (from $20 \%$ in 1995 to $8 \%$ in 1996 - for total exports, and from $25 \%$ to $9 \%$ respectively - for exports to non-CIS states). In 1997 total exports fell for the first time since 1992. Needless to say, it was Russia's already weak export of manufactured goods that was most affected by the appreciation of real exchange rate. In 1996 among economies in transition Russia (together with Slovenia - by far the richest country, experiencing recovery from 1993) had the smallest gap between domestic and international prices ${ }^{3}$.

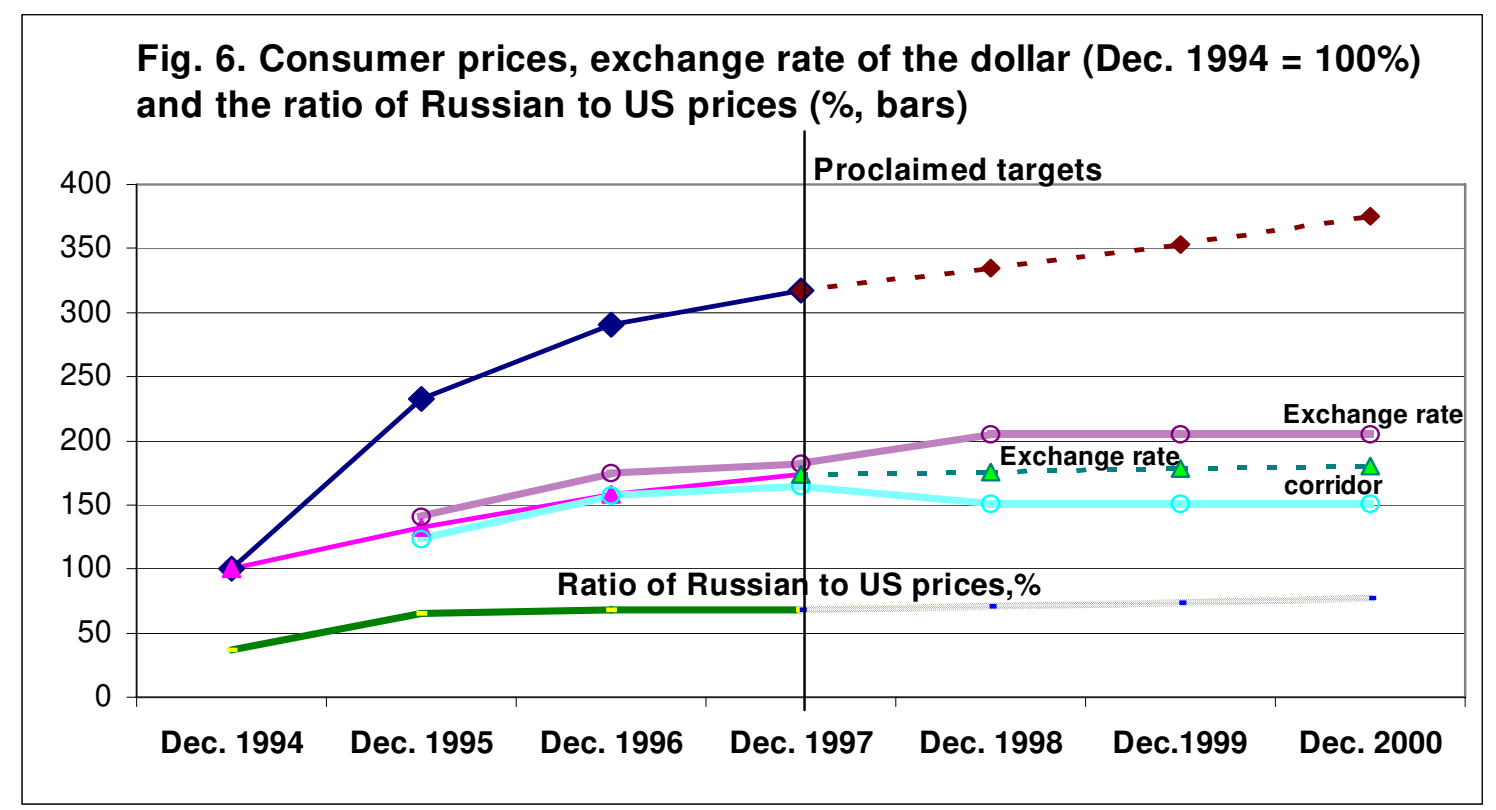

Source: Goskomstat.

\footnotetext{
3 See table and Popov, 1996a, b and 1998b.
} 
The decrease in the oil prices in the world market in 1997-98 added insult to injury: the reduction of export accelerated in the first half of 1998, which together with still rising import virtually wiped out completely the trade surplus, which in better times, in 1996, amounted to $\$ 20$ billion (fig. 8). The current account turned into negative in the first half of 1998 (fig. 9). Given the need to service the debt and the continuation of the capital flight (which is partly captured in the "errors and omissions" in the balance of payments statistics (Smorodinskaya, 1998 - fig. 9), the negative current account was the sure recipe for disaster.
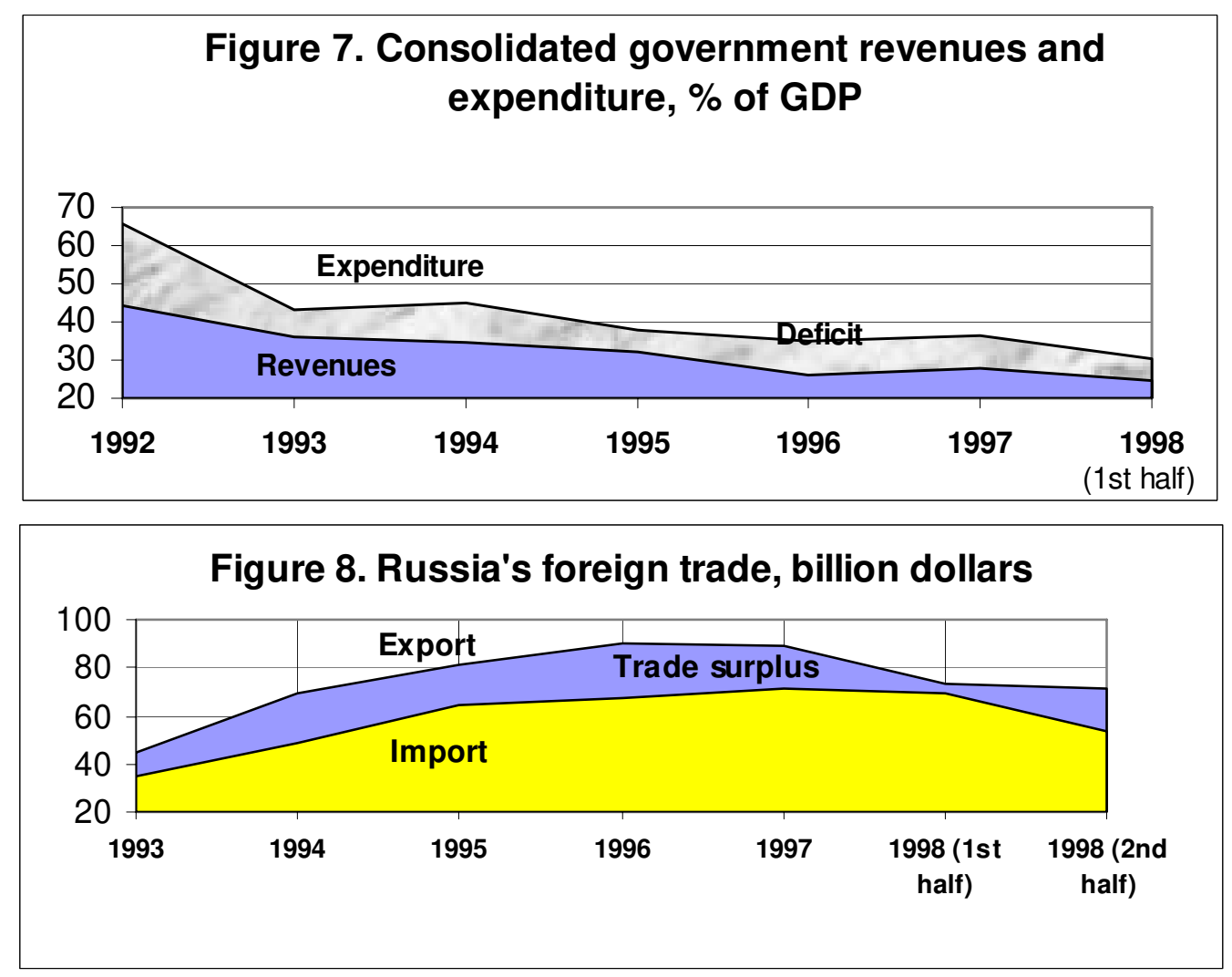

Source: EBRD, 1996, 1997, 1998.

In fact, under the circumstances the exchange rate became hardly sustainable in 1998 since there developed a new vulnerability of the rouble with respect to short-term capital flows. Foreign investment into rouble denominated government treasury bills since they were allowed by authorities in 1995 quickly increased to nearly $1 / 3$ of $\$ 50$ billion market for government treasury bills in 1997 (including investment into the GKO through "grey schemes", i.e. through resident intermediaries). From February 1998 the total amount of T-bills held by the non residents started to exceed the value of the country's foreign exchange reserves (Economist, May 23, 1998) - just like in Mexico since June 1994 the value of dollar denominated Tesobonos exceeded total reserves (Griffith-Jones, 1997). 


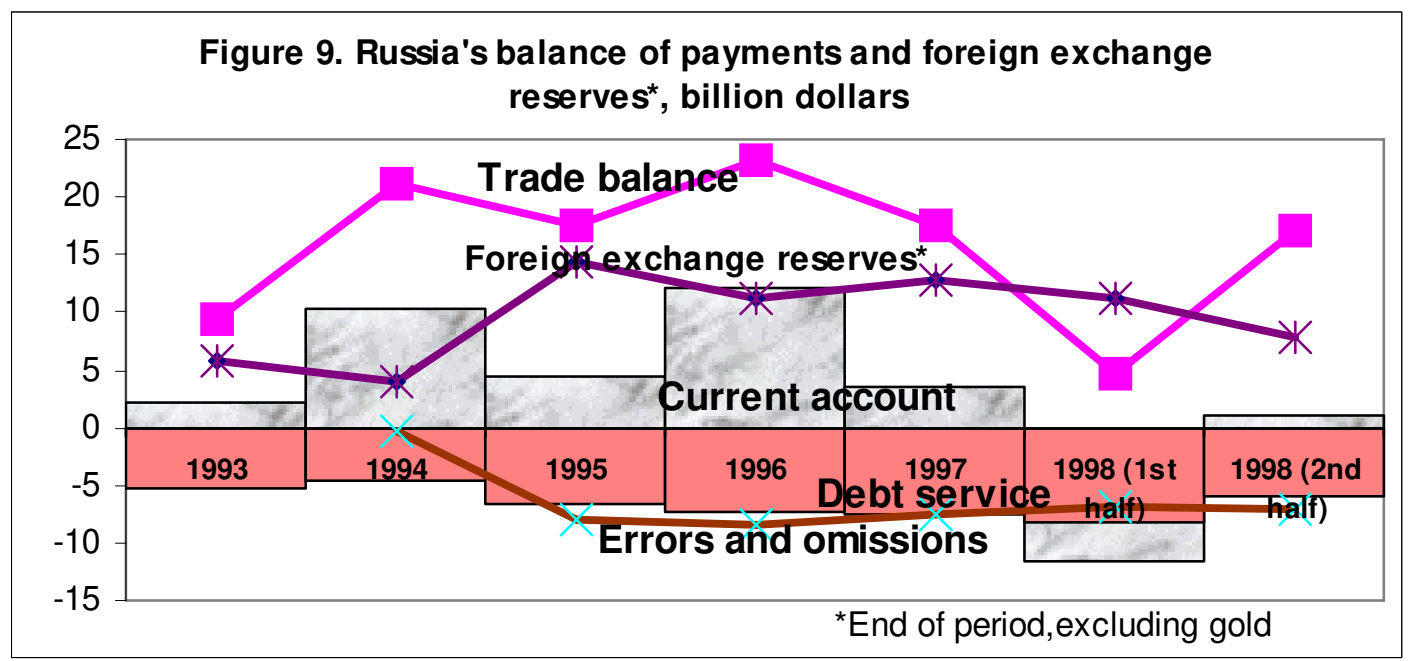

Source: Goskomstat.

Foreign investors also started to withdraw from the Russian stock market. They were estimated to control no less than $10 \%$ of the shares in the booming Russian stock market whose capitalisation surpassed $\$ 100$ billion in the fall 1997. Since that time until mid 1998 - in just about 9 months - the stock prices in dollar terms fell by over $80 \%$ to the lowest level since 1994 (fig. 10). The decision of the CBR to expand slightly the width of the exchange rate band from the beginning of 1998 (fig. 6) was a cosmetic measure and has not yielded much room for the manoeuvre. The Central Bank had to increase the refinancing rate to $150 \%$ in May 1998 to prevent capital from fleeing at a rate of about $\$ 0.5$ billion a week at a time when foreign exchange reserves were at level of about $\$ 15$ billion only. Later the refinancing rate was lowered, but yields on government securities remained at a level of nearly $50 \%$ in real terms and then again increased to over $100 \%$ in August. The central bank and the government, however, were sticking to the policy of strong rouble up to the very last moment, maintaining scandalously high interest rates that eliminated all prospects for economic recovery and negotiating a stand-by package with the IMF. In a sense this was a policy designed to maintain consumption and imports, to avoid export-oriented restructuring and to continue to live beyond the means. The IMF finally provided the first instalment ( $\$ 4$ billion) of the $\$ 20$ billion dollar package that went directly to the CBR to replenish vanishing foreign exchange reserves, but even this did not calm the investors. Public officials' statements about the stability of the rouble, including that of Yeltsin made 3 days before devaluation, had only the opposite effect, if any.

Managing the August 1998 crisis. As a number of other economists 4 , I strongly believed before the crisis broke out that the rouble is overvalued, arguing that if it is not devalued "from above" in advance, it is likely to get devalued "from below", in the form of the currency crisis, with much greater costs (Popov, 1996 a, b, 1997, 1998 b, e). ${ }^{5}$ In a

\footnotetext{
${ }^{4}$ See, for instance: Illarionov (1998), Shmelev (1998).

5 This argument was also developed in the newspapers articles. See: Growth Strategy. - Segodnya, March 14, 1996 (in Russian); The Currency Crisis Is Possible in Russia. - Finansoviye Izvestiya, October 30, 1997
} 
sense, it was not so difficult to predict the crisis and quite a number of scholars did so several months ahead of time. Even Jeffrey Sachs, earlier the strong advocate of the exchange rate based stabilisation, in June 1998 spoke out publicly in favour of devaluation (New York Times, June 4, 1998)6.

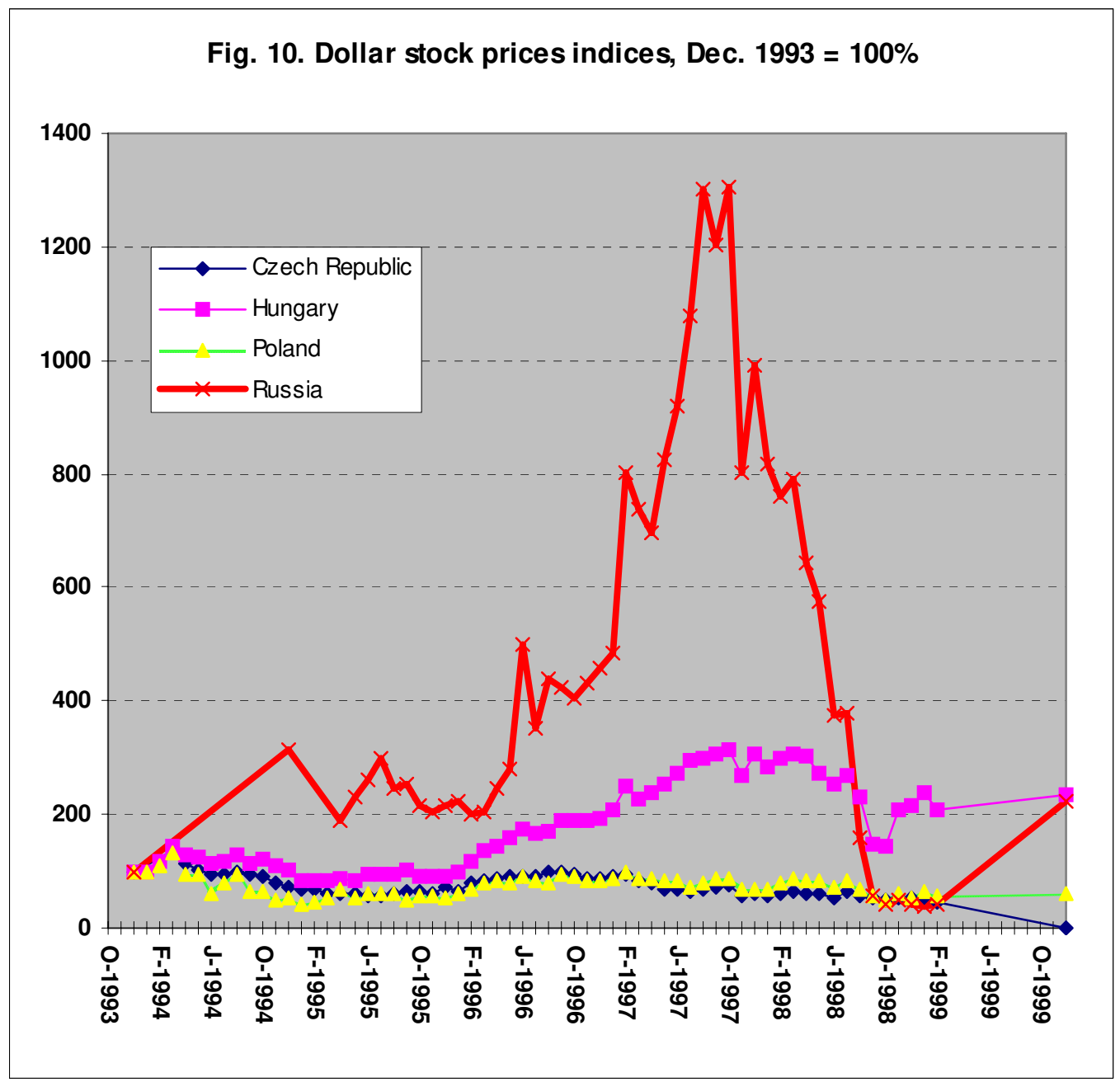

Source: Economist. (For Russia in 1992-93 - author's estimates).

What virtually nobody was able to predict, is the way the Russian government handled the devaluation, i.e. by declaring the default on domestic debt and part of the

(in Russian); An Emerging Economy's Unaffordable Luxury - Financial Times, Dec. 11, 1997; What Exchange Rate of the Rouble Is Needed for Russia? - Nezavisimaya Gazeta, May 21, 1998 (in Russian); Arithmetic of Devaluation: Why Do We Need a Rate of 12 Roubles per Dollar. - Nezavisimaya Gazeta, June 1998 Supplement (in Russian).

6 The other major proponent of the exchange rate based stabilization and also the former adviser of the Russian government, Anders Aslund, pretty much like IMF, continued to deny the need to devalue even in July (his article "Don't Devalue the Ruble" in Moscow Times, July 7, 1998). 
international debt held by banks and companies. This was by no means necessary, since basically there was no debt crisis, but only the currency crisis, which was supposed to be handled only by means of devaluing the rouble.

As fig. 11 suggests, the indebtedness of the Russian government in recent years was growing, but not that significantly as compared to GDP (since GDP in dollar terms was growing rapidly due to the real appreciation of the rouble). In absolute terms the total government debt by mid 1998 has not even reached the threshold of 60\% of GDP. Even when the wage and payment arrears of the Russian government are taken into account, total indebtedness does not increase much: government wage arrears right before the crisis stood at 13 billion roubles, or just $0.5 \%$ of annual GDP, whereas total government arrears that were several times higher than just wage arrears were largely offset by tax arrears to the government.

True, government short term obligations - GKOs, rouble denominated, but held by nonresidents, since early 1998, according to available estimates, exceeded total foreign exchange reserves, which was an obvious mismanagement and clearly contributed to the crisis. However, the absolute value of the outstanding short term debt held by the foreigners was by no means substantial - only $\$ 15-20$ billion. The problem rather was the negligible amount of reserves ( $\$ 15$ billion), but even under these circumstances it was possible to continue to service the debt after, say 50\% devaluation (which would immediately decrease debt service payments twice in dollar terms), not to speak about the IMF credits 7 .

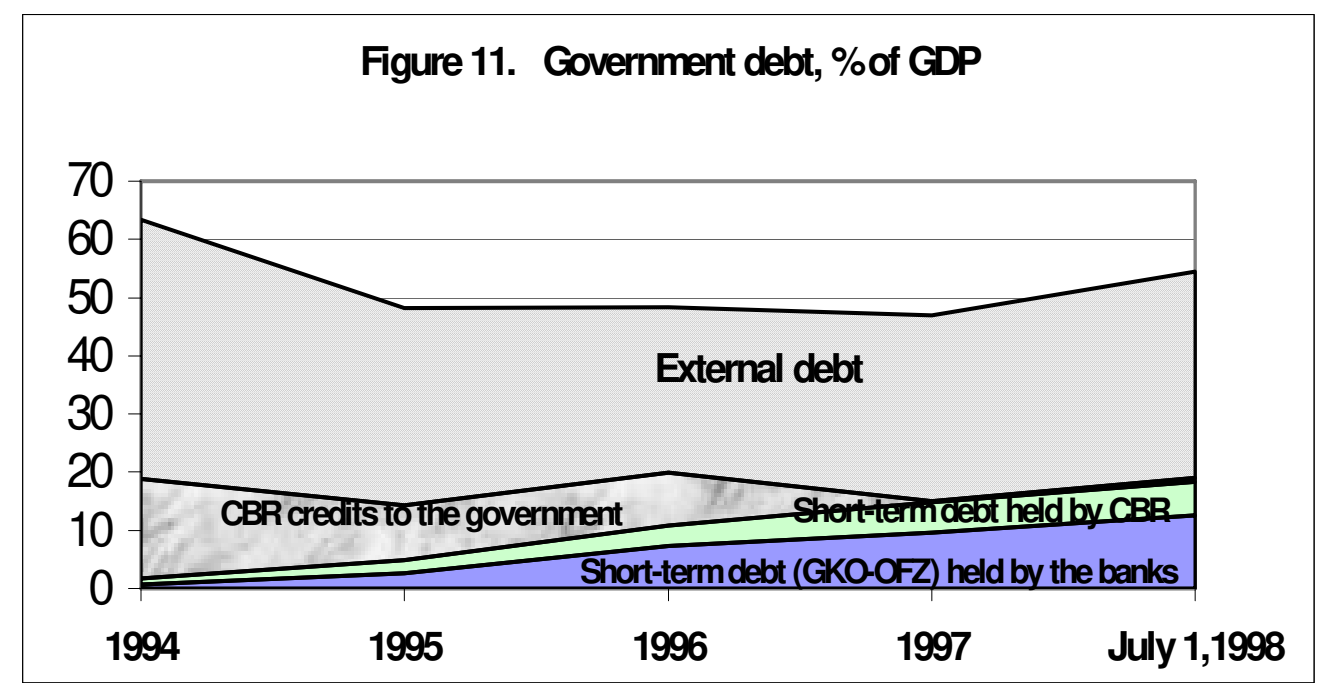

Source: Russian Economy. The Month in Review. No. 1, 1998. Bank of Finland, Institute for Economies in Transition; Goskomstat.

\footnotetext{
${ }^{7}$ This was a sharp contrast to the Mexican situation in the second half of 1994. Like in Russia, the value of outstanding short-term government debt exceeded the amount of foreign exchange reserves. But unlike Russian GKOs, Mexican Tesobonos were denominated in dollars, not in national currency, so devaluation of the peso could not and did not decrease the dollar value of the debt.
} 
The mistrust of investors in the first half of 1998 was associated first and foremost with the low credibility of the government course to defend the ruble, whereas the ability of the government to service its debt was not really put into question. The difference between the rates at which the Russian government borrowed abroad in hard currency (returns on Eurobonds were around 15\%) and the rates offered to the prime borrowers (7\%) was much lower than the gap between returns on ruble denominated bonds (about $100 \%$ in real terms) and Eurobonds (15\%). Because the first gap is the indicator of the country risk (i.e. the risk associated with the default by the government of this particular country), whereas the second one reflects the currency risk (i.e. the risk associated with the devaluation), it is clear that the anticipation of the market at that time was that of devaluation, but not of default.

Unfortunately, the default was not the only mismanagement in handling the crisis. Shortly after the default the CBR provoked by its clumsy actions a run on the banks and a banking crisis. Banks already were badly hurt by the devaluation (which was inevitable cost they were supposed to take), but also by the default (because they held a considerable portion of their assets in short-term government securities, on which the government defaulted, and also because they lost opportunities for external financing after the government imposed a 90 days moratorium on servicing their external debts). To make matters worse, the CBR in early September introduced a scheme to guarantee personal deposits in commercial banks, which implied losses for the depositors, especially for the holders of dollar accounts at private banks 8 . The run at the banks that naturally followed contributed to the developing paralysis of the banking system - in September 1998 banks were hardly processing any payments and businesses started to carry out their transactions purely in cash, barter and cash substitutes.

After the crisis. The ailing Russian industry after the August 1998 financial crash experienced a boom, registering high growth rates that were not seen for nearly half a century. Industrial output was more or less stable for three years in 1995-97; the decline started in the very beginning of 1998 and continued until August 1998 currency crisis totalling 15\%; the recovery is occurring since September 1998 at a rate of about $1 \%$ a month (fig.12). Strong growth has started not because of, but despite the government policy: whereas before the crisis the overvalued rouble was undermining the competitiveness of domestically produced goods, after devaluation domestic producers are taking advantage of new export opportunities and the shift in demand from foreign to Russian made goods.

In fact, the recent 1998 recession that occurred before the crisis was artificially manufactured by the poor policy of keeping the exchange rate at an unreasonably high and unsustainable level. The market corrected the mistake of the government and the

\footnotetext{
${ }^{8}$ In state owned Sberbank (Savings Bank) that accounted for $75 \%$ of all household deposits savings were guaranteed by the state. CBR, while extending the guarantees to the personal deposits at commercial banks, asked the depositors to move them to Sberbank, promising to pay them back only in 2 months and only in part (dollar deposits, for instance, were supposed to be converted into rubles at a September 1 rate of 9.33 rubles per dollar, whereas the market rate of the dollar was already about 2 times higher.
} 
central bank backed by IMF that defended the unsustainable peg with persistence that deserved a better application - this is what the August 1998 crisis was all about. Different patterns of the decline of output in Russia (before the currency crisis) and in East Asia (after the currency crisis) provide another evidence of the different nature of the currency crashes: whereas in East Asia, where exchange rates were not overvalued, the devaluation led to adverse supply shock coupled with the depressing effects of the collapse of the previously overextended credit, in Russia devaluation of the previously overvalued currency restored the previously lost competitiveness and led to the increase in capacity utilisation rates ${ }^{9}$. Unlike East Asian countries, Russian economy experienced a boom after the currency crisis, not a recession.

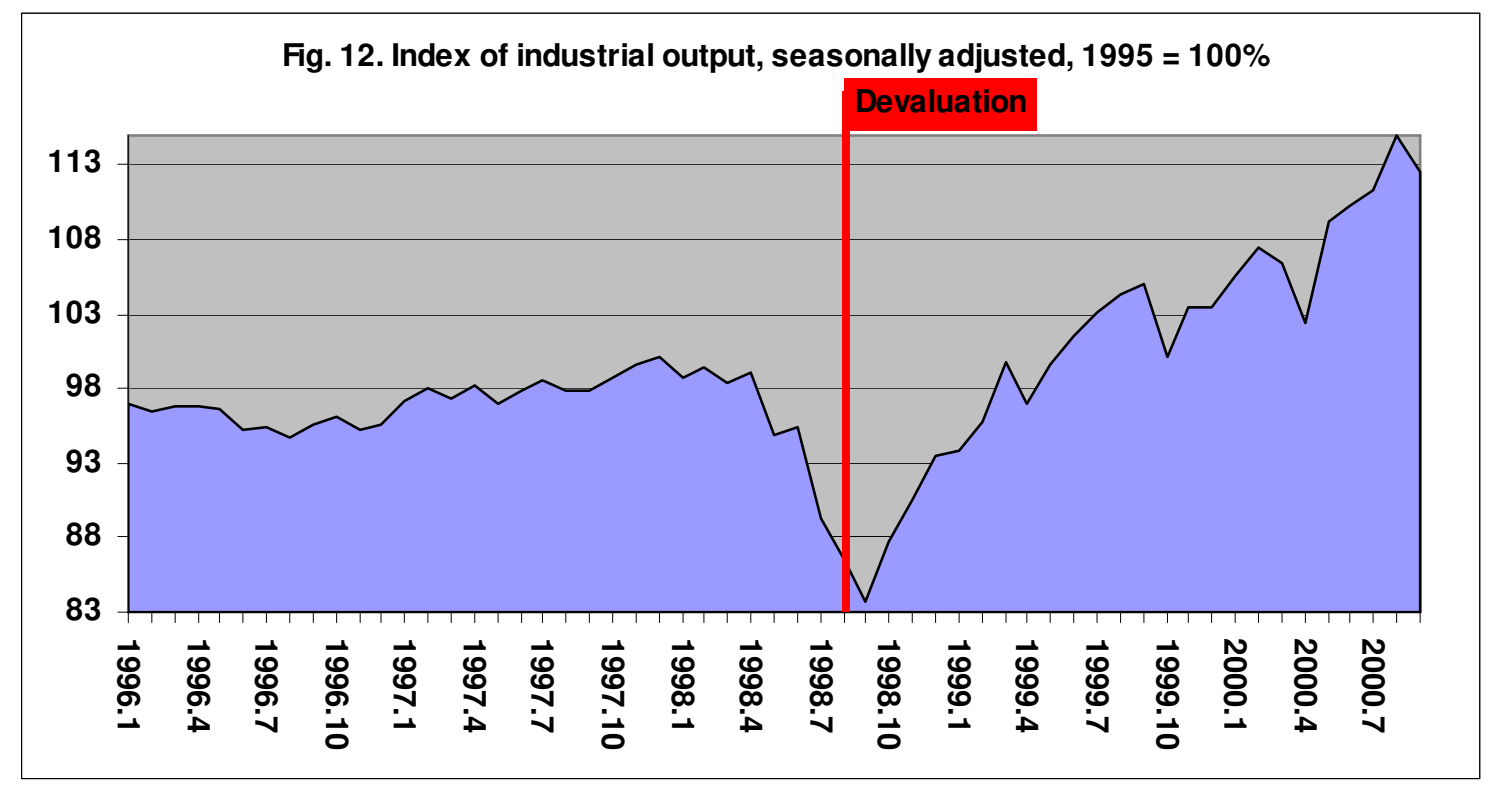

Source: Russian Economic Trends.

\section{Other versions of the story: alternative explanations of the Russian crisis}

There are several prevailing (and not mutually exclusive) explanations for the August 1998 currency crisis in Russia. One stresses the unfortunate coincidence of events (Asian virus, a drop in oil prices, political instability, etc.). Yevgeny Yasin (1999), the minister without portfolio in the former Kirienko government and a respected academic economist, says "the crisis is not just the result of the evil forces or incompetence, but is caused by the coincidence of circumstances, most of which were against us". Sergey Kirienko himself even now believes that even in June 1998 Russia had a chance to get through the bumpy piece of the road avoiding the crisis, had only the Duma accepted tax increases suggested by the government (Expert, January 18, 1999). Aslund takes a similar stand, noting that by rejecting in July 1998 the government package of sensible policies the Duma pushed the country "over the brink into a financial abyss" (Aslund, 1999b).

\footnotetext{
${ }^{9}$ For more details on the differences between the currency crises in Latin America, Southeast Asia and Russia see: Montes, Popov, 1999; Popov 2000b.
} 
Another explanation is that the crisis was caused by the budgetary problems - persisting deficits resulting in mounting government debt, or "the GKO pyramid". (Russian Economy..., 1999). No wonder, the former high officials of the Central Bank of Russia (CBR) take this view. "No doubt, the current financial crisis is mostly of budgetary and debt origin", - states Sergey Alexashenko, the then deputy chairman of the CBR (Alexashenko, 1999). It is thus the government, not the CBR, to be blamed, since it was only that much and that long that the CBR was able to stick to the restrictive monetary policy without being supported by the government, which continued to pursue loose fiscal policy. The former government officials in response say they knew about the problem, but were not able to force the parliament to accept the necessary tough measures to improve tax collection. Hence the scapegoat of last resort is again the redbrown parliament, which, as everyone is supposed to know, is so anti-reform minded.

One variation of these views is that the construction of the government debt pyramid was doomed to collapse and eventually collapsed. It is pointed out that the returns on the short-term government bonds (GKOs) were scandalously high, many times higher than in the real sector, and that such a policy was driving away resources from the real sector into purely financial speculations in the market for government debt and the stock market (Nekipelov, 1998). Financial prosperity, not based on the foundations of the healthy real economy could not continue for long and finally came to an end in the form of the crisis.

The Western explanations of the Russian crisis, at least those that appear outside the area studies field, are generally even more straightforward. The most popular alternative explanations for the Russian crisis are associated one way or another with the crony and criminal nature of the Russian capitalism. The government is accused of playing in the interests of "oligarchs" - heads of large financial-industrial groups in the Russian economy - that have effectively "privatised" the state and care only about enriching themselves in the short run. The assumption basically is that everything is so rotten in Russia that there is no way the exchange rate can be stable.

It seems like the majority agreed that everything is so rotten in Russia that it would be strange, if the crisis did not happen. It is often stated that funds obtained by the state through domestic and external borrowing were mishandled, if not embezzled or stolen, and that overall the inefficient and corrupt system of the public administration cannot ensure any kind of macroeconomic stabilization, be it exchange rate based of money based. Oligarchs are not thinking long-term anyway and are unable to agree on measures on increasing tax revenues of the state, slowing down capital flight and controlling the indebtedness, since, as Paul Krugman puts it, 'there is no honor among the thieves" (Krugman's site, Sept. 10, 1998), suggesting that the IMF - World Bank credits were just wasted, if not stolen, by the short-sighted and apres-nous-le deluge-minded oligarchs. Aslund (1999a) believes that August 1998 crash became the outcome of intense competition over the evasive rent that decreased from 15-80\% of GDP in 1991-94 to 5$15 \%$ in $1995-98$.

Some go even further, seeing the root of all Russia's evils in misunderstanding of the nature of money. References are being made to the Russian national character (described, for instance, in the "Gambler" by F. Dostoyevsky, where Alexei states that Russians are 
squanders and like roulette so much exactly because it allows to become rich effortlessly in two hours), as well as to 70 years of bolshevism that virtually abolished money as a legal tender of predictable value, making the value rouble "something stranger than zero" (Economist, Dec. 19, 1998).

These explanations, however, may be journalistically impressive, but to a large extent miss the point. First, although the role of money and credit in the Soviet centrally planned economy (CPE) was limited, as compared to the market economy, the degree of monetisation (M2/GDP ratio) and creditisation (bank credit outstanding as a \% of GDP) in the 1980s was much higher than in the Russian market economy of the 1990s (about $50 \%$ as compared to less than 15\%). So in a sense the Soviet CPE was much more monetised than the new Russian market economy. Soviet planners, as a matter of fact, were quite prudent in their macroeconomic policies for four decades - from 1947 (Stalin's confiscatory monetary reform) to 1987 (the beginning of macroeconomic mismanagement under Gorbachev) the annual average inflation (open and hidden, i.e. the increase in monetary overhang) was only $3 \%$, less than in most countries in this period. Government budget deficits were low or non-existent, government domestic debt was minuscule, external indebtedness was low, and payments were made clockwork.

To put it differently, the argument about the "demonetised Russian soul" does not seem to work, as well as the argument about "difficult Soviet heritage", since neither of the factors prevented Soviet planners from achieving high degree of macro stability and solid monetisation of the economy.

Second, there is hardly any doubt that Russian state institutions were degrading in recent years and that the weakening of the state institutions is the main long-term factor explaining the poor performance of the Russian (and CIS) economy as compared to China and Vietnam with strong authoritarian institutions, on the one hand, and Central European countries with strong democratic institutions, on the other. As a matter of fact, recent research study comparing 28 transition economies, including those of China and Vietnam, suggests that it is not the speed of liberalisation, which should be held responsible for differing performance, but the institutional capacity of the state - the factor that was overlooked by both schools of transition thought - by shock therapists and by gradualists (Popov, 1998 c, d; 2000a). Such an approach seems to gain more and more support in the framework of so called "post-Washington consensus" (Stiglitz, 1998, 1999).

Nevertheless, even though the institutional weakness is the single most important longterm factor that contributed to the extreme magnitude of the Russian recession, it is not linked directly with the collapse of the rouble and the failure of macroeconomic stabilisation program. As was argued earlier, the debt levels of the Russian government and Russian companies were very modest by the international standards: even if the borrowed funds were embezzled, this could not and did not lead to the debt and currency crises, since the critical point of really excessive indebtedness was yet to be reached in at least several years. No less important, there was no major change with respect to "cronyness", corruption and institutional weaknesses in recent years (except, may be for, some stabilisation), so references to the criminal nature of Russian capitalism cannot explain much. 
Finally, the goal of maintaining the appropriate (not overvalued) exchange rate is perhaps the least politicised issue of the government economic policy: by keeping the rouble low through carrying out timely and gradual devaluation, the government and the CBR were not risking any opposition neither from industrial lobbies, nor from oligarchs. While there are reasons to believe that macroeconomic stabilisation in Russia did not materialise in 1992-94 because the of the lack of consensus among powerful industrial lobbies on how to finance cuts in government expenditure (Popov, $1996 \mathrm{a}, \mathrm{b}$ ), there is no evidence whatsoever that a low rouble strategy in 1995-98 was not acceptable because of political considerations.

\section{Currency crises: theory and evidence}

It may be useful to distinguish between currency (foreign exchange) crisis per se and more complicated cases of debt (financial) and credit (banking) crises. The latter two, even if they mature in countries with strong currencies usually lead to the currency crisis as well.

Foreign exchange (currency) crisis. This first type of the crisis can occur even without capital flows, creditors, lenders and banks. The only necessary precondition for the currency collapse (abrupt change in the exchange rate) is the peg of the exchange rate by the central bank or the attempts to maintain the flexible rate (dirty float) at an unsustainable level. If the monetary policy in the country is too different from that of its neighbours, the demand for and the supply of foreign exchange gets out of the equilibrium, the downward or upward pressure on the currency emerges and subsequently leads to devaluation/revaluation.

In case of the downward pressure on the currency the ability of the central bank to defend it is limited by the amount of foreign exchange reserves, which are usually enough at most for only several months of import financing and for several days of financing of capital outflows; whereas in case of upward pressure on the currency the central bank's ability to defend the national currency through building up foreign exchange reserves is constraint by the inevitable inflationary consequences of growing money supply or by the readiness to proceed with the sterilisation operations, which lead to higher interest rates (and to new capital inflows).

Once a brisk devaluation/revaluation occurs, it causes shifts in relative prices and terms of trade, which may provoke a supply side recession, not to speak about changes in relative prices of assets denominated in foreign and domestic currencies, which may cause disruptions in the repayment of credits (debt and banking crises).

This type of the currency crisis was described initially by Krugman as a balance of payments crisis (1978); he later called it "a canonical currency crisis model", in which the crisis results from "a fundamental inconsistency between domestic policies - typically the 
persistence of money-financed budget deficits - and the attempt to maintain a fixed exchange rate" (Krugman, 1979).

The argument developed in this paper is that this is exactly the type of currency crisis that occurred in Russia in August 1998: straightforward "plain vanilla" currency crisis caused by the overvaluation of the national currency - the ruble - since the time of the introduction of the exchange rate corridor in mid 1995. Because the exchange rate was overvalued, the export growth slowed down and finally stopped completely, whereas import continued to rise, so that the current account shrank and even turned negative in the first half of 1998, whereas the capital outflow accelerated in view of the possible devaluation. This led to the trivial depletion of the foreign exchange reserves, which were not that large even before the crisis ( $\$ 15$ billion in the beginning of 1998): the emergency credits of the IMF (the first tranche of \$4 billion was handed out in July 1998) were used in about 4 weeks and the devaluation followed on August 17.

The consequences of what was and should have been a pure currency crisis were aggravated, however, by the clumsy actions of the government, which overreacted by defaulting on its own short term domestic debt and by imposing a 90-days moratorium on servicing the external debt by private banks and companies. These latter measures were by no means necessary since there was basically no debt crisis and no banking crisis in the making. But after the government defaulted on its debt obligations, both, debt and banking crises, broke out.

The government debt crisis. This second type of the currency crisis is the one that is caused by the inability of the government to honor its' debt obligations. If the debts are denominated in foreign currency, like Mexican Tesobonos in 1994, the connection is obvious: the outflow of capital in the expectation of the default and/or devaluation leads to the reserve depletion and triggers devaluation. If the obligations are denominated in domestic currency, investors being afraid of the inflationary financing of the public deficits (leading to inflation and devaluation) switch to foreign exchange. Mexican peso in 1994 and many Latin American currencies in the early 1980s were undermined by exactly this kind of mechanism: the outflow of capital caused by the mistrust in the ability of the government to pay back their debts brought down even those currencies in Latin America that were strong and not overvalued.

Krugman (1997) argues that currency crises caused by mounting accumulation of debt are covered by "so called second generation models", which assume that the governments weigh costs and benefits of abandoning the peg: once investors realize that the advantages of the depreciation of the debt denominated in domestic currency are greater than the disadvantages associated with devaluation, they attack the currency and the crisis breaks out.

Debt crisis of the private sector. This third type of the currency crisis is the one that occurs due to the banking crisis, or, to be more precise, because of the overaccumulation of the private debts (banks and companies), not because of the indebtedness of the government. It occurred in 1997-98 in the Southeast Asia (SEA) and became a surprise 
for at least some economists, since currency crises of this type were by no means common since the abandonment of the gold standard in 1914.

In the words of Paul Krugman (1998), the currency crises in Asia "were only part of a broader financial crisis, which had very little to do with currencies or even monetary issues per se. Nor did the crisis have much to do with the traditional fiscal issues", but rather was related to issues "normally neglected in the currency crisis analysis: the role of financial intermediaries (and the moral hazard associated with such intermediaries when they are poorly regulated), and the prices of real assets such as capital and land". The Asian story, he continues, is not a problem brought up by fiscal deficits, as in "first generation models", nor is one brought on by macroeconomic temptation, as in "second generation models". It is really a story of a bubble in and subsequent collapse of asset values in general, with the currency crises more a symptom than a cause of this underlying real malady.

The so called "Lawson doctrine", named after the UK Chancellor of the Exchequer Nigel Lawson, assumed that the government is supposed to care only about "its own fundamentals", i.e. about its own indebtedness and about budget deficits, whereas the current account deficits and debts resulting from the activities of the private sector would be taken care of by the market mechanisms (Montes, 1998). However, the assumption that the costs of risky borrowings by the private sector will be internalized proved to be wrong - non-government debt crises (which finally led to currency crises) broke out in Asian countries, which had nearly perfect fundamentals: high saving ratios, strong growth, undervalued rather than overvalued currencies, low inflation, government budget surpluses and low government debt. It was exactly the excessive borrowing of the private sector abroad (banks in Thailand, industrial companies in Indonesia, chaebols in Korea, etc.) that caused the mistrust of investors and resulted in the outflow of capital and the currency crises.

How the three types of the currency crises interact. The suggested classification is of course a rough scheme, since every particular currency crisis is caused by a variety of factors and usually combines the features of all three types of mechanisms. Sachs, Tornell and Velasco (1996) examine the predictive power of three indicators, which are close to discussed factors contributing to currency crisis: real currency appreciation (i.e. overvaluation of the exchange rate in our terminology), the ratio of M2 to foreign exchange reserves (the indebtedness of the public sector) and strength of recent lending booms (the indebtedness of the private sector). They find that out of 20 examined emerging market economies those that were particularly hard hit by the 1994-95 crisis (Mexico, Argentina, Brazil) displayed in the preceding period not only rather low reserve ratios, but experienced strong real appreciation of currencies and lending booms. Similarly, the rapid growth in the ratio of bank credit to GDP preceded earlier financial troubles in Argentina (1981), Chile (1981-82), Colombia (1982-83), Uruguay (1982), Norway (1987), Finland (1991-92), Japan (1992-93) and Sweden (1991).

Nevertheless, the recent Asian currency crises were unique in a sense that there were virtually no preceding disequilibriums in the government sector: macroeconomic strategy 
- fiscal and monetary policy, exchange rate and debt management - was prudent and reasonable and by no means calling for trouble.

\section{Economic analysis: exchange rate policy for transition and developing economies}

One of the basic stylised facts about the exchange rates in transition economies is the substantial appreciation of the real exchange rate after deregulation of prices and introduction of the convertibility. Out of major EE and FSU economies only in Slovenia real exchange rate was relatively stable, whereas in other countries there was a more or less prolonged (several years) period of real appreciation of national currencies.

However, in most countries real appreciation by the mid 1990s slowed down and in some stopped completely. Moreover, in 1996-98 8 post-communist countries with previously rapidly appreciating real exchange rates (Bulgaria, Romania, Belarus, Ukraine, Russia, Kyrghyzstan, Georgia and Kazakhstan - in chronological order) have witnessed the collapse of their currencies (fig.1). In all 8 countries the brisk devaluation of the currencies was no less significant than in Asia in 1997-98 (with the exception of Indonesia, where the rupiah at one point lost $80 \%$ of its value) and no less significant than in Mexico in 1994-95. In fact, in Bulgaria and Russia, where currencies depreciated by nearly $2 / 3$, it was more significant, and in Belarus - even more significant than in Indonesia (fig. 1, 2).

Why these currency crises occurred? Has the real appreciation of currencies before the crisis in these countries gone too far? This paper argues that the answer to the above question is positive and that the overappreciation of exchange rates should be held responsible for those crises.

Unlike in Latin American countries post-communist governments were not considerably indebted, and unlike in South East Asian countries companies and banks in former centrally planned economies (CPE) did not manage to accumulate sizeable debts. Most communist governments were quite prudent in accumulating external debts; besides, for many countries external debts were written off on the eve of transition (Russia assumed all debts of the FSU, so that other newly created FSU states started their existence with no indebtedness at all, part of the Poland's debt was written off, etc.). On the other hand, companies and banks in transition economies (which under CPE were not allowed to borrow abroad) do not have much of a credit history and are just starting to accumulate foreign debts (Popov, 2000b).

Undervaluation of domestic currency is a common feature for most developing and transition countries since they usually need to earn a trade surplus to finance debt service payments and capital flight 10 . Unlike in mature market economies, in most poorer countries the exchange rates of national currencies is low as compared to PPP (Popov,

${ }^{10}$ Hölscher (1997) is making a similar argument with respect to EE countries drawing on the West German experience with undervalued mark in the 1950s. 
2000b). For resource rich countries, however, there is a danger of "Dutch disease", which arises because resource exports is so profitable that it allows to earn a trade surplus even under the overpriced exchange rate. Thus, Middle East countries (mostly oil exporters) are the only major group of states in developing world with the exchange rate close to PPP .

On the other hand, many other developing countries (including those rich in resources) pursue the conscious policy of low exchange rate as part of their general export orientation strategy. By creating a downward pressure on their currencies through building up foreign exchange reserves, they are able to limit consumption and imports and to stimulate exports, investment, and growth.

This used to be the strategy of Japan, Korea, Taiwan and Singapore some time ago, when those countries were still poor and were catching up with high income states. This is currently the strategy of many new emerging market economies, especially that of China, which continues to keep the exchange rate at an extremely low level (5 times lower than PPP rate) by accumulating foreign exchange reserves at a record pace. It is by no means an accident that all very fast growing economies are also famous for high and rapidly growing international reserves: China (including Hong Kong), Taiwan, Singapore, Malaysia, Thailand, account for a good $20 \%$ of total world reserves, whereas reserves to GDP ratio for these countries is normally above $20 \%$ as compared to only $8 \%$ for the world as a whole (World Bank, 1998).

Sterilisation is often viewed as a self defeating policy, since it is achieved only at a cost of higher domestic interest rates, which in turn leads to the greater inflow of capital, the need for the new sterilisation and thus even higher interest rates, etc. However, in practice sterilisation is usually carried out by countries exercising some kind of capital control, either administrative or in the form of the Tobin tax, which makes sterilisation policy efficient.

To put it differently, there are generally two major reasons for relatively low exchange rates - (1) the generally lower level of development, imposing the burden on the balance of payments in the form of the capital flight and debt service payments (non-policy factor) and (2) the governments/central banks conscious policy to underprice the exchange rate in order to use it as a instrument of export-oriented growth (policy factor).

If the discussed factors apply equally to the development and transition economies, it means that there is the equilibrium level of the exchange rate (and it is substantially below PPP rate). The continuous appreciation of real exchange rate is thus an invitation for a trouble and should sooner or later result in the currency crisis.

The specifics of the exchange rate policy in transition economies are determined, among other factors, by the challenge of macroeconomic stabilisation, which the policy maker faced in most post-communist countries after the deregulation of prices. Economists and policy makers tend to disagree on what kind of exchange rate policy is best for economies in transition. Some stress the importance of maintaining the stable nominal 
exchange rate by fixing it and using as a nominal anchor to fight inflation - exchange rate based stabilisation (Bofinger, Flassbeck, and Hoffmann, 1997). Others claim that real exchange rates are supposed to be kept stable (which implies constant devaluations, if inflation is higher than elsewhere) - so as to ensure that the actual rate is substantially below PPP rate - in order to stimulate export and growth.

The conventional shock-therapy approach to macroeconomic stabilisation recommends to use the pegged exchange rate as a nominal anchor while pursuing an anti-inflationary policy Sachs, 1994, 1995; Åslund, 1994). There is certainly a reason in such an argument: high exchange rate by increasing import competition helps to hold down inflation - in fact this was the case in many EE and FSU countries, including Russia in 1995-98.

However, as noticed above, virtually all transition economies experienced an appreciation of real exchange rate since the start of the transition, (table) which undermined the competitiveness of exporters, worsened the current account, and forced to maintain high interest rates (to slow down the capital flight and attract new foreign financing) at a time when exactly the opposite was needed. By now it appears that even in those countries which avoided the currency crisis, the real appreciation of the exchange rate becomes a major policy concern.

In countries which exercised the currency board arrangements longer than others (Estonia - since June 1992 and Lithuania - since October 1994), domestic prices continued to grow despite the stability of the nominal exchange rate, so that due to real appreciation of their currencies the current account deficit in 1998 increased to over 10\% of GDP and its financing totally depends on the inflow of foreign capital. Both countries until now managed to withstand the Asian crisis and the Russian crisis, but their growth rates in 1998-99 fell significantly and even turned negative.

Overall, by now the major problem in the region seems to be the overvaluation of the national currencies hindering economic growth and creating the threat of the currency crises, not the lack of stable exchange rates. There seems to be a growing recognition of the fact that the exchange rate is far too important to use it only for fighting inflation. Even more so, that most transition economies currently achieved macroeconomic stability and are preoccupied mostly with economic growth. Exchange rate management as a weapon to fight inflation can play only a limited role, and at the end of the day inflation has to be dealt with at its source, i.e. high budget deficits, unregulated banking systems, fragile revenue collections (Desai, 1998).

The policy of keeping the real exchange rate stable, instead of pegging the nominal rate, appears to appeal more to policy makers now, after the currency crises of 1996-98. Even more so that countries pursuing this kind of policy for quite a time now are doing no worse than others. Zettermeyer and Citrin (1995) found that money-based stabilisation has been successful in quite a number of countries (Albania, Slovenia, Croatia, FYR Macedonia) and there was no evidence that it is an inferior strategy to pegging the exchange rate for fighting inflation. With an appropriate monetary policy (at least partial sterilisation of increases in the money supply caused by foreign exchange reserves build 
up) the inflationary pressure may be dealt with, as proven by the example of many emerging market economies.

Table. Ratio of the actual exchange rate to the PPP rate of the dollar for selected economies in transition (range of monthly averages)

\begin{tabular}{|c|c|c|c|c|c|c|c|c|c|c|}
\hline $\begin{array}{l}\text { Country } \\
\text { /Year }\end{array}$ & 1990 & 1991 & 1992 & 1993 & 1994 & 1995 & 1996 & 1997 & 1998 & 1999 \\
\hline Slovenia & $0.9-1.4$ & $1.0-1.7$ & $1.4-1.6$ & $1.4-1.6$ & $1.3-1.6$ & $1.1-1.3$ & $1.3-1.3$ & $1.4-1.5$ & $1.3-1.5$ & $1.3-1.5$ \\
\hline Hungary & $1.9-2.4$ & $1.9-2.0$ & $1.7-1.8$ & $1.6-1.8$ & 1.6-1.8 & $1.5-1.6$ & $1.7-1.8$ & $1.6-1.8$ & $1.7-1.8$ & $1.7-1.8$ \\
\hline Poland & $2.1-3.9$ & $1.6-1.9$ & $1.8-2.0$ & $1.8-2.0$ & $2.1-2.3$ & $1.8-2.0$ & $1.8-1.8$ & $1.8-2.1$ & $1.8-2.0$ & $1.9-2.1$ \\
\hline $\begin{array}{l}\text { Czech } \\
\text { Republic }\end{array}$ & $2.5-3.8$ & $3.5-3.1$ & $2.7-3.1$ & $2.5-2.6$ & $2.2-2.5$ & $2.0-2.2$ & $1.9-2.0$ & $2.0-2.3$ & $1.8-2.3$ & $1.9-2.3$ \\
\hline $\begin{array}{l}\text { Slovak } \\
\text { Republic }\end{array}$ & $2.9-3.9$ & $3.0-3.6$ & $2.9-3.0$ & $2.6-2.8$ & $2.4-2.7$ & $2.1-2.3$ & $2.1-2.2$ & $2.3-2.4$ & $2.2-2.4$ & $2.3-2.7$ \\
\hline Croatia & & & & & & & & $1.7-1.9$ & $1.7-1.9$ & $1.8-2.0$ \\
\hline Lithuania & - & - & - & - & $2.4-3.2$ & $1.8-2.3$ & $1.7-1.8$ & $1.5-1.6$ & - & - \\
\hline Romania & $1.8-2.6$ & $1.6-5.0$ & $2.8-4.2$ & $2.2-3.1$ & $2.1-2.6$ & $2.1-2.5$ & $2.4-2.6$ & $2.0-3.3$ & $1.7-2.0$ & $2.0-2.3$ \\
\hline Bulgaria & $3.3-5.1$ & $2.9-10.9$ & $3.0-4.7$ & $2.3-2.8$ & $2.3-3.1$ & $1.8-2.2$ & $1.9-2.8$ & $1.7-3.2$ & $1.6-1.8$ & $1.6-1.9$ \\
\hline Ukraine & - & - & - & - & - & $1.8-2.5$ & $1.3-1.7$ & 1.3-1.4 & $1.3-2.1$ & $2.0-2.7$ \\
\hline "RUSSIA & - & $\begin{array}{l}33.0- \\
131.0 \\
\end{array}$ & $\begin{array}{l}10.2- \\
45.7 \\
\end{array}$ & $2.5-8.0$ & 2.4-2.8 & 1.4-2.4 & 1.4-1.5 & 1.4-1.5 & 1.5-2.8 & $2.7-2.9$ \\
\hline
\end{tabular}

Source: PlanEcon.

The problem, of course, is that there are political obstacles for adopting economically optimal policy. An exchange rate overvaluation occurred in Russia and other transition economies despite the experience of other (Latin American) countries and despite the understanding that such a policy may have ruinous consequences.

\section{Political economy of exchange rate overvaluation}

The political-economic foundations for sub-optimal policies in transition economies seem to be no different than in other countries - at least here the post-socialist states appear to be far from being unique. A decade ago the research on the macroeconomics of populism in Latin America raised a similar question and suggested two answers: (1) sharp asset and income inequalities (as compared to Asian countries) and (2) sharp division between primary products export sector controlled by the traditional oligarchy and employers and workers in industry and services (Kaufman and Stallings, 1991). It was argued that upper income groups are generally in a good position to resist taxation and this placed a limit on the capacity of Latin American governments to deal with distributive pressures within the context of the growth-oriented export models. In small open European economies the expansion of the welfare state allowing to adjust painlessly to costs of internationalisation, was an important political concomitant of liberal trade policies. In East Asian countries political weight of urban popular groups (pressing for redistribution of export revenues in their favour) was counterbalanced by the presence of the large class 
of independent farmers or small export-oriented manufacturing firms. In contrast, in Latin America the state had a much more limited capacity to tax income and assets directly, and the export-oriented oligarchy was not willing to share its revenues, but at the same time not able to resist the pressure for redistribution because of political isolation.

The heritage of the CPE put the transition economies into a situation, somewhat similar to Latin American countries. Whatever were the reasons for the wide scale redistribution income in former socialist countries, in the very beginning of transition, after the deregulation of prices, they experienced a dramatic and quick increase in personal income inequalities and sectoral inequalities in the profitability of enterprises. Previously, under authoritarian regimes, the government was strong enough to impose substantial burden of transfers on the producers (the government revenues in most former socialist countries were way above $50 \%$ of GDP). Weak democratic governments, however, facing falling budget revenues, were not in a position to maintain large scale open subsidisation and had to choose between gradually eliminating the bulk of all subsidies and finding alternative ways of financing these subsidies (inflationary financing, building up domestic and foreign debt, maintaining the overvalued exchange rate, driving foreign borrowing up and/or foreign exchange reserves down).

The inability to cut subsidies inherited from the era of central planning, observed mostly in the CIS region (where the newly emerged democratic governments were weak), was the major reason for the macroeconomic instability experienced by these countries budget deficits, inflation, increased domestic and foreign indebtedness, overvalued exchange rates leading to currency crises.

Once there is a need, whether mythical or real, to redistribute income in favour of poorest social groups and weakest enterprises, coupled with the inability of the governments to raise enough taxes for this redistribution activity, the story unfolds pretty much in line with Latin American type macroeconomic populism (Dornbush and Edwards, 1989; Sachs, 1989) and leaves a strong sense of déjà vu. Constraint by inability to raise tax receipts and by the simultaneous need to maintain redistribution in favour of particular social groups, the governments are left basically with only several options for indirect financing of subsidies: (1) to maintain control over particular prices, generally for resource goods in order to take away rent of resource sector and redistributes it to consumers; (2) trivial inflationary financing of the government budget; (3) debt financing of the budget deficit - either domestic or external borrowing; (4) subsidisation through the accumulation of non-payments, barter transactions and monetary substitutes - here transition economies showed something new in the economics of subsidies and macro stabilisation, this type of redistribution was previously unknown on such a scale.

Finally, the fifth way to continue redistribution with no funds in the budget is to maintain the overvalued exchange rate that favours consumers over producers, importers over exporters and leads to increase in consumption at the expense of savings. Consumption increases in this case due to increase in imports financed through external borrowing or foreign exchange reserves, and obviously provides only a temporary solution, leading to the balance of payments crisis in the longer term. It was shown for developing countries 
that overvaluation of the exchange rate is detrimental for economic growth (Dollar, 1992; Easterly, 1999).

Overvaluation of the exchange rate is usually supported by the governments (that collect their taxes in domestic currency, but service the international debt in foreign currency) and, of course, by the importers, whose political influence may exceed that of exporters (Bates and Devarajan, 1999). Transition economies that maintained the overvalued exchange rates (and that later, in 1998-99, experienced the currency crises) and in particular Russia, pose a number of questions in this respect. Although Russian exports is highly concentrated (several resource commodities and only a couple of dozen of companies), major exporters before 1998 crisis were not pushing for a lower rate 11 .

This is another reason why exchange rate based stabilisation and currency board arrangements are quite risky for transition economies (Montes and Popov, 1999). Opening the possibility for the appreciation of real exchange rate (and ensuring equilibrium only through balance of payments crisis) these arrangements allow also for the continuation of populist policies - redistribution of income from producers to consumers. At the end of the day inflation has to be dealt with at its source, i.e. high budget deficits, unregulated banking systems, fragile revenue collections, so exchange rate management as a weapon to fight inflation can play only a limited role (Desai, 1998).

Different countries in different periods resorted to one or more of the described above mechanisms of implicit redistribution. In Russia, for instance, the government was initially (1992-94) relying on controlling resource prices and inflationary financing. Since 1995, when exchange rate based stabilisation was carried out and the rouble reached $70 \%$ of its purchasing power parity value (i.e. Russian prices, including resource prices approached $70 \%$ of the US prices, which was the apparent overvaluation of the rouble), the government relied mostly on debt (domestic and foreign) financing and redistribution via overvalued exchange rate. Since 1998 financial crisis, however, leading to the collapse of the overvalued rate and to the cessation of international and domestic debt financing, the government has to rely largely on price control (via export taxes and export restrictions) on major tradable goods (oil, gas, metals).

\section{Concluding comments}

There are two important general policy lessons for transition economies and other similar economies undertaking market reforms which have almost instantly given them access to foreign capital resources. First, they need to avoid real exchange rate appreciation that led to current currency crises. Second, given that they find themselves in a trend of increasing external indebtedness, they have to draw early lessons from more complex

11 Of all Russian "oligarchs" and main exporters only one (Boris Berezovsky) spoke out openly in favour of devaluation before the August 1998 crisis, whereas the others (Vladimir Potanin, for instance) publicly opposed devaluation until the very last moment. 
government debt crises (Latin American countries in early 1980s and in 1994-95) and private sector debt crises (Southeast Asia in 1997-98) to avoid another episode of currency collapses in the near future.

Even with the stable domestic financial system it may be impossible for small countries to withstand the attack on their currencies in the world where daily foreign exchange reserves are less than the volumes of capital outflows for several days and less than the assets of major Western investment funds. In the absence of control over the destabilising short term capital flows in donor countries and at the level of international financial organisations, the recipient countries have to adopt rules and procedures allowing to protect their financial systems from volatile international capital markets.

Preventing the appreciation of real exchange rate. Unlike the currency crises in East Asia, and the preceding currency crises in Latin America, recent currency crises in transition economies seem to be caused not by excessive debt - private or government accumulation, but by mere appreciation of the exchange rate, undermining the competitiveness of the export sector, leading to the deterioration of the current account and finally causing the outflow of capital in the anticipation of the devaluation. Theories that were offered to explain the trend towards the real exchange rate appreciation in transition economies proved to be of limited applicability. At the end of the day, in transition economies, as well as in other countries, the appreciation of the real exchange rate cannot be infinite, and, if it goes too far, leads to the crisis.

Besides, the policy of keeping the exchange rate low through the accumulation of reserves seems to be not only prudent, but also conducive to economic growth. For transition economies facing the challenge of export oriented restructuring it is highly desirable. The inflationary consequences of such a policy, as the example of East Asian countries shows, may be dealt with through sterilisation operations.

However, no matter how optimal the low exchange rate policy may be from a purely economic point of view, there are important political economic factors that push the real exchange rate up. Overvalued exchange rate favours consumers over producers, exporters over importers and leads to increase in consumption at the expense of savings. Consumption increases in this case due to increase in imports financed through external borrowing or foreign exchange reserves. Such a redistribution in favour of importers and consumers may be an important part of the social pact, as was the case in many Latin American countries in the 1970s and 1980s. Strong government willing and able to withstand such populist pressure is required to break this type of the vicious circle.

Exchange rate based versus money based stabilisation. Whereas exchange rate based stabilisation may work at the initial stages of transition for fighting inflation, there is a growing evidence that at later stages it becomes an obstacle for economic growth and creates the potential of the currency crisis by allowing the real exchange rate to appreciate.

Bringing inflation down to single digits in transition and other emerging market economies with a lot of market imperfections and structural rigidities is by itself a questionable policy. True, in countries with highly inflationary environment chances are high that output growth will be weak, if any. However, it was shown, that $40 \%$ a year 
inflation is sort of a threshold: there is no evidence that inflation below $40 \%$ annually is ruinous for growth, while there is even some evidence that inflation below 20\% a year may be even beneficial (see Bruno and Easterly, 1995; Bruno, 1995; Stiglitz, 1998). It may be even argued that the threshold for transition economies is actually higher than for other emerging markets because of the numerous structural rigidities. In most successful reformers inflation was by no means insignificant: it never fell below $20 \%$ a year in the first 5 years of transition in Poland and Uzbekistan, while in China, though it was low most of the time, there were outbursts of inflation in 1988-89 and in 1993-95, when it increased to about $20 \%$.

It seems like Russian authorities in this respect went from one extreme (very high inflation of 1992-94) to the other, trying to be more catholic than the Pope. Since exchange rate based stabilisation program was enacted in 1995, it was pursued with greater diligence than elsewhere: right before the crisis, in July 1998, the year to year inflation was brought to the lowest level of $6 \%$ - less than in most transition economies. Arguably this low level of inflation did impose unnecessary strains onto the economy, causing the avalanche of non-payments and leading to the lack-of-demand-induced reduction of output. In fact, after the modest growth in 1997, output started to decline in the first half of 1998.

Fixed versus flexible rates. Given the relatively small size of most emerging market economies and their rapidly growing, but not yet full involvement into the world economy, floating exchange rates may provide more flexibility while adjusting to the external shocks. Most developing and transition economies, with the exception of the smallest ones, like Hong Kong, Singapore and perhaps Baltic states) are large enough to remain not completely exposed to the world market competition and hence to retain some inflexibility of domestic prices with respect to the world market prices. Nevertheless, they are not large enough to create an appropriate cushion in the form of foreign exchange reserves, bringing down the vulnerability resulting from the international capital flows to reasonable levels. In most emerging markets (with the possible exception of China) foreign exchange reserves are normally enough to withstand several weeks, if not days of the attack on the currency. More than that, because the major international banks, investment and hedge funds operate with the pools of money comparable with or even exceeding the value of reserves in most countries, the fluctuations of the exchange rate remain the only reliable and efficient safety valve providing protection from external shocks.

With fixed exchange rates, or, even more so - with currency board arrangements, effectively forcing countries to abandon their independent monetary policy, they are doomed to adjust to the inflows and outflows of capital through real indicators: when the exchange rate is pegged and prices are not completely flexible, changes in the money supply (caused by the fluctuation of reserves) may affect output rather than prices. And as the recent experience of East Asian and transition economies showed, this kind of real sector adjustment is quite costly. To put it in the simplest form, under fixed exchange rate regime, neither changes in foreign exchange reserves, nor domestic price changes in response to money supply fluctuations provide enough room for manoeuvre for handling international capital flows. 
Openness of capital accounts and strength of the banking system. For transition economies, where the currency crises, as was argued earlier, were not triggered by the debt and lending boom, there is an important lesson to be derived from the East Asian experience about "twin liberalisations" - that of capital account and that of domestic financial systems. As debt levels, both - government and private - in these economies continue to grow, measures should be taken to ensure that safety and reliability of banking institutions is not overrun by the openness of the capital accounts.

In Russia, for instance, the credit and banking crisis, as was argued earlier, was by no means necessary and was in fact manufactured by the poor policies (the government default on its short term debt and the CBR measures that undermined the credibility of commercial banks). Nevertheless, no matter from where the blow came, it revealed the long known and discussed weaknesses of the domestic banking system. In a sense, it was shown that next time, when the shock would come from the international capital flows, Russian banks will not be able to withstand it unless prudential regulations are tightened and the viable banking sector is created. Before the short term capital flows are regulated by the source countries and international financial institutions, the continuation of the policy of nearly complete openness to capital flows may be the invitation for trouble.

\section{REFERENCES}

Alexashenko, S. (1999), The Battle for the Rouble. Alma Mater, 1999 (in Russian).

Asian Development Bank (1997), Asian Development Outlook 1997 and 1998, 1997.

Åslund A. (1994), The Case for Radical Reform. Journal of Democracy, Vol. 5, No. 4, October 1994.

Aslund, A. (1999a), Why Has Russia's Economic Transformation Been So Arduous. World Bank's Annual Bank Conference on Development Economics, Wash., D. C., April 28-30, 1999.

Aslund, A. (1999b), Russia’s collapse. - Foreign Affairs, Sept./Oct. 1999.

Bates, R., Devarajan, S. (1999). "Framework Paper on the Political Economy of African Growth", mimeo.

Bofinger, P., Flassbeck, H., and Hoffmann L. (1997), "Orthodox Money-Based Stabilization (OMBS) versus Heterodox Exchange Rate-Based Stabilization (HERBS): the Case of Russia, the Ukraine and Kazakhstan". - Economic Systems, Vol. 21, No. 1 (March 1997), pp. 1-33.

Bruno, Michael, and Easterly, William (1995), Inflation Crisis and Long-Run Growth. Unpublished. World Bank. 
Bruno, Michael (1995), Does Inflation Really Lower Growth? - Finance \& Development, September 1995.

Desai, Padma (1994), Aftershock in Russia's Economy. - Current History, Vol.93, No.585, October 1994, p.320-3.

Desai P. (1997), Russia. - In: Going Global: The Transition From Plan to Market in the World Economy. Ed. by P. Desai. Cambridge, MIT Press, 1997, pp.317-51.

Desai P. (1998). Macroeconomic Fragility and Exchange Rate Vulnerability: A Cautionary Record of Transition Economies. - Journal of Comparative Economics, 26 (4), 1998, pp.621-41.

Dollar, D. (1992). "Outward-oriented developing economies really do grow more rapidly: evidence from 95 LDCs, 1976-1985”, Economic Development and Cultural Change, 40 (3), April: 523-44.

Dornbush, Rudiger and Edwards, Sebastian (1989), The Economic Populism Paradigm. NBER Working Paper 2986, Cambridge, Mass., 1989.

Easterly, William (1999), The Lost Decades: Explaining Developing Countries Stagnation 1980-1998. World Bank, 1999.

EBRD (1997). Transition Report 1997. EBRD, London, 1997.

EBRD (1998). Transition Report 1997. EBRD, London, 1998.

EBRD (1999). Transition Report 1999. EBRD, London, 1999.

Goskomstat: Narodnoye Khozyaistvo SSSR (National Economy of the USSR), Rossiysky Statistichesky Yezhegodnik (Russian Statistical Yearbook) and monthly publications for various years. Moscow.

Griffith-Jones, S. (1997), "Causes and Lessons of the Mexican Peso Crisis". Working paper No. 132, WIDER/UNU.

Hölscher, J. (1997), Economic Dynamism in Transition Economies: Lessons from Germany. - Communist Economies and Economic Transformation, Vol. 9, No. 2, 1997, pp. 173-81.

Illarionov, A. (1998), How the Russian Financial Crisis Was Organized. - Voprosy Ekonomiky, No. 11,12, 1998 (in Russian ).

IMF (various years), International Financial Statistics, Washington, DC. 
Kaufman, Robert R. and Stallings, Barbara (1991), The Political Economy of Latin American Populism. - In: Macroeconomics of Populism in Latin America. Ed. By R. Dornbush and S. Edwards. Chicago and London, 1991.

Krugman, P. (1979), "A model of balance of payments crises", Journal of Money, Credit, and Banking , 11: 311-325.

Krugman, P. (1997), "Currency crises" (prepared for NBER conference, October 1997). Http://web.mit.edu/krugman/www/crises.html

Krugman, P. (1998), "What Happened to Asia?" January 1998. Http://web.mit.edu/krugman/www/DISINTER.html

Mau, V., (1998), Political Nature and Lessons of Financial Crisis. - Voprosy Economiky, No.11, 1998 (in Russian).

Montes, M. (1998), "Currency Crisis in Southeast Asia". Updated edition. 1998. Institute of Southeast Asian Studies, Singapore.

Montes, M., Popov, V. (1999), The Asian Crisis Turns Global. Institute of Southeast Asian Studies, Singapore, 1999.

Naughton, B. (1997), Economic Reform in China. Macroeconomic and Overall Performance. - In: The System Transformation of the Transition Economies: Europe, Asia and North Korea. Ed. by D. Lee. Yonsei University Press, Seoul, 1997.

Nekipelov, A. (1998), The Nature of Russia's Economic Catastrophe - An Alternative Diagnosis. - Transition. The Newsletter About Reforming Economies, October 1998.

PlanEcon, Washington, DC, various issues.

Popov, V. (1996a), Inflation During Transition: Is Russia's Case Special. - Acta Slavica Iaponica, Tomus XIV, 1996, Sapporo, Japan, pp. 59-75

Popov, V. (1996b). A Russian Puzzle. What Makes Russian Economic Transformation a Special Case. WIDER/UNU, RFA 29, 1996.

Popov, V. (1997), Lessons from Currency Crisis in Southeast Asia. - Voprosy Ekonomiky, 1997, No. 12 (in Russian).

Popov, V. (1998a), "Investment in Transition Economies: Factors of Change and Implications for Performance". - Journal of East-West Business , Vol. 4, No. 1/2.

Popov, V. (1998b), Preparing Russian Economy for the World Market Integration. - In: Regionalisation and Globalisation in the Modern World Economy. Ed. by A. Fernandez Jilberto and Andre Mommen. Routledge, London, 1998, pp. 86-127. 
Popov, V. (1998c), Economic Outcomes of Transformation: The Impact of Initial Conditions and Economic Policy. - Voprosy Ekonomiky, No.7, 1998 (in Russian).

Popov, V. (1998d), Institutional Capacity Is More Important than the Speed of Reforms. - Voprosy Ekonomiky, No.8, 1998 (in Russian).

Popov, V. (1998e), Will Russia Achieve Fast Economic Growth? - Communist Economies and Economic Transformation, 1998, No. 4.

Popov, V. (1999a), The Financial System in Russia as Compared to Other Transition Economies: The Anglo-American versus The German-Japanese Model. - Comparative Economic Studies, No. 1, 1999.

Popov, V. (1999b), Russia's Financial Collapse. - NIRA Review, Winter 1999, Vol. 6, No.1.

Popov, V. (1999c), Exchange Rates in Developing and Transition Economies. - EKO, No.5, 1999, pp.40-52 (in Russian).

Popov, V. (1999d), Lessons from the Currency Crises in Russia and in Other Countries. Voprosy Ekonomiky, No. 6, 1999, (in Russian).

Popov, V. (2000a), Shock Therapy versus Gradualism: The End of the Debate (Explaining the Magnitude of the Transformational Recession). - Comparative Economic Studies, Spring, 2000, Vol. 42, No.1, pp.1-57.

Popov, V. (2000b), The Currency Crisis in Russia in a Wider Context. - C.D. Howe Institute Commentary, No. 138, March 2000 (http://www.cdhowe.org/eng/PUB/frame.html).

Russian European Centre for Economic Policy (various years), Russian Economic Trends.

Russian Economy in 1998 (1999). Trends and Prospects. Institute of Economics of Transition, Vol. 20, March 1999 (in Russian).

Sachs J. (1994), "Russia's Struggle with Stabilization: Conceptual Issues and Evidence”. A paper prepared for the World Bank's Annual Conference on Development Economics. Washington, D.C., April 28-29, 1994.

Sachs J. (1995), "Why Russia Has Failed to Stabilize". Working Paper No.103, Stockholm Institute of East European Economics, 1995.

Sachs, J.,Tornell, A.,Velasco A. (1996). Financial Crises in Emerging Markets: The Lessons from 1995. Brookings Papers on Economic Activity, 1:1996, pp. 147-98. 
Stiglitz, Joseph (1998). More Instruments and Broader Goals: Moving Toward the PostWashington Consensus. WIDER Annual Lecture. WIDER/UNU.

Stiglitz, J. (1999). Whither Reform? Ten Years of Transition. World Bank's Annual Bank Conference on Development Economics, Wash., D. C., April 28-30, 1999.

Shmelev, N. The Crisis Inside the Crisis. - Voprosy Ekonomiky, 1998, No.10.

Shmelev, N., Popov, V., The Turning Point: Revitalizing the Soviet Economy. New York, Doubleday, 1989.

Smorodinskaya, N., Capital Flight in Theory and in Practice: The Analysis of the Russian Situation. - Banking Services, No. 9, 1998 (in Russian).

UNCTAD (1999), World Economic Situation and Prospects for 1999. N.Y., Geneva, 1999.

World Bank (1996), From Plan to Market. World Development Report, NY: Oxford University Press, 1996.

World Bank (1997), The State in A Changing World. World Development Report, NY: Oxford University Press, 1997.

World Bank (1998), World Development Indicators 1998.

Yasin, E. Defeat or Retreat? (Russian Reforms and Financial Crisis). Report to Economic Club. Moscow, January 1999 (in Russian).

Zettermeyer J., Citrin D. (1995), Stabilization: fixed versus flexible exchange rates. Policy experiences and issues in the Baltics, Russian and other countries of the former Soviet Union, IMF, Washington, DC, 1995. 